\title{
MAXIMIZING STAKEHOLDERS' INTERESTS: AN EMPIRICAL ANALYSIS OF THE STAKEHOLDER APPROACH TO CORPORATE GOVERNANCE
}

\author{
Silvia Ayuso \\ Miguel Angel Rodríguez \\ Roberto García \\ Miguel Angel Ariño
}




\title{
MAXIMIZING STAKEHOLDERS' INTERESTS: AN EMPIRICAL ANALYSIS OF THE STAKEHOLDER APPROACH TO CORPORATE GOVERNANCE
}

\author{
Silvia Ayuso* \\ Miguel Angel Rodríguez ${ }^{* *}$ \\ Roberto García*** \\ Miguel Angel Ariño $0^{* * *}$
}

\begin{abstract}
The purpose of the present paper is to help bring some advances in the characterization of the emerging stakeholder model of corporate governance. This shall be achieved by analyzing CSR function at board level, board diversity and stakeholder engagement and by examining its relationship with financial performance. Based on an empirical study of an international sample of large companies, we found board responsibility for CSR to be a key factor in promoting engagement with primary and secondary stakeholders of the firm. Depending on the legal tradition of the country where the company is based, we found evidence that board diversity and stakeholder engagement are positively related to firm financial performance.
\end{abstract}

\footnotetext{
* Postdoctoral Research Fellow, IESE

** Lecturer, General Management, IESE

*** PhD Candidate, IESE

**** Professor, Managerial Economics, IESE
}

Keywords: Corporate governance, corporate social responsibility, board diversity, stakeholder engagement, firm performance 


\section{MAXIMIZING STAKEHOLDERS' INTERESTS: AN EMPIRICAL ANALYSIS OF THE STAKEHOLDER APPROACH TO CORPORATE GOVERNANCE*}

\section{Introduction}

The current debate on corporate governance theories has been polarized between a shareholder perspective and a stakeholder perspective (Letza et al., 2004; Szwajkowski, 2000; Vinten, 2001). These two contrasting paradigms have different ways of understanding and justifying fundamental questions concerning the purpose of the corporation and its associated structure of governance and arrangements. On one side is the traditional shareholding model that regards the corporation as a legal instrument for shareholders to maximize their own interests, i.e. investment returns. On the other side is the relatively new stakeholding approach that views the corporation as a locus of responsibility related to wider external stakeholders' interests rather than merely to shareholders' wealth. Employees, creditors, suppliers, customers and the local community are major stakeholders often mentioned and emphasized within a broad definition of stakeholders.

Beyond this theoretical debate, it can be observed that current measures of good governance practices are for the most part consistent with agency theory, the dominant approach underpinning the shareholder perspective (Wheeler and Davies, 2004). Typically, these measures analyze the duties of the board and their agents (i.e. the CEO and senior management), their mutual independence, the oversight of compensation and other incentives and mechanisms for assuring accountability for shareholders' wealth (e.g. market for corporate control). However, the empirical evidence on the impact of these board structures and processes is inconclusive. For instance, Dalton et al. (1998) conducted a meta-analysis of data from 85 studies and found no

\footnotetext{
* We would like to thank SAM Group, and especially Edoardo Gai, for the help and support providing the data for this paper. The views expressed in this paper are those of the authors and do not necessarily represent those of SAM Group. All the corporate indicators used in the present study have been independently elaborated by the authors of this article from the original data provided by SAM Group. Any possible error in the interpretation or manipulation of such data remains the sole responsibility of the authors.

Earlier versions of this paper were presented at the European Academy of Management (EURAM) Annual Conference, Oslo, 17-20 May 2006 and at the Strategic Management Society (SMS) Annual International Conference, Vienna, 29 October-1 November 2006.
} 
evidence of any consistent, systematic relationship between governance structure and financial performance, irrespective of the type of performance indicator, the size of the firm or the manner in which board composition is measured.

Recent corporate governance codes emphasize stakeholder governance practices, often in connection with social and environmental responsibility (Wieland, 2005). However, despite the growing attention given to these issues (e.g. Alkhafaji, 1998; Clarke, 1998), there has been little research on how to integrate the interests of all the different stakeholders into the corporation's decision-making and management processes and on the effects of adherence to these practices. Although scholars of corporate governance have distinguished a Continental-European/Japanese stakeholder system from an Anglo-American shareholder system, these highly stylized portraits are primarily used to explain differences between countries in finance, ownership, labor relations and the role of the market in corporate control, as well as to explore the possibilities of convergence or continued divergence in corporate governance practices (Aguilera and Jackson, 2003). Less attention has been paid to concrete mechanisms for involving a wide array of stakeholders in company governance and for using these mechanisms as a way of addressing the needs of diverse stakeholders within a strategy of corporate social responsibility (CSR).

Thus, the purpose of the present paper is threefold. First, it tries to advance in the firm-level characterization of the emerging stakeholder approach to corporate governance by proposing three dimensions for this kind of corporate governance model: CSR function at board level, board diversity and stakeholder engagement. Second, it intends to examine the relationship between conformance to the stakeholder model of corporate governance and firm financial performance. Third, it explores differences between countries by using an international sample of large companies. Even though we acknowledge that the stakeholder orientation to corporate governance considers a set of objectives that go beyond financial and market performance (such as more qualitative relational aspects of performance involving trust and commitment), here we will focus exclusively on financial measures as a quantitative indicator for this wider organizational performance.

This paper is structured as follows: in the next section we review the relevant literature on the stakeholder approach to corporate governance and develop the hypotheses that we are going to test; following this, we present the data and the results of the empirical analysis; finally, we discuss the contributions and limitations of the paper and finish with some conclusions.

\section{Literature review and hypotheses development}

\section{The stakeholder approach to corporate governance}

Stakeholder theory can be traced back to the seminal work of Freeman (1984), who articulated a new conceptual model wherein firms must address the interests of their stakeholders - groups and individuals who can affect or are affected by the organization's activities. This 'stakeholder model' proposes extending the focus of managers beyond the traditional interest group of shareholders in order to understand the needs, expectations and values of groups previously perceived to be external to the company. In this sense, stakeholders of a firm can be defined as "individuals and constituencies that contribute, either voluntarily or involuntarily, to its wealth-creating capacity and activities, and who are therefore its potential beneficiaries and/or risk bearers" (Post et al., 2002, p. 58). Stakeholder 
theory has both normative (moral/ethical) and instrumental (profit/wealth-enhancing) implications, since dealing with stakeholders can be regarded as a responsibility to meet the legitimate claims of all stakeholders and/or as a means to maximize organizational wealth (Donaldson and Preston, 1995; Jones, 1995; Jones and Wicks, 1999).

In corporate governance, the normative stakeholder theory has its origins in the social entity conception of the corporation, developed in the later part of the $19^{\text {th }}$ century (Letza et al., 2004). This theory regards the corporation as a public association constituted through political and legal processes and as a social entity for pursuing collective goals with public obligations (see e.g., Gamble and Kelly, 2001, p. 115). With the fundamental value of human rights and morality as a reference framework, it is argued that "the standard of a corporation's usefulness is not whether it creates individual wealth but whether it helps society gain a greater sense of the meaning of community by honoring individual dignity and promoting overall welfare" (Sullivan and Conlon, 1997, p. 713). This view of the corporation as an entity that serves corporate and social interests has been acknowledged by the normative or moral standpoint of stakeholder theory (e.g., Carroll, 1996).

Instrumental stakeholder theory is often connected with the pluralistic model of corporate governance (Letza et al., 2004). Like social entity theory, the pluralistic model claims that a corporation should serve multiple interests of stakeholders rather than shareholder interests alone. However, it legitimizes stakeholder value not on the basis of its intrinsic worth but as an effective means to improve efficiency, profitability, competitiveness and economic success. In that sense it argues that stakeholders who make firm-specific investments and contributions and bear risks in the corporation should participate in corporate decision-making as a way of enhancing corporate efficiency (e.g., Blair, 1995; Kelly and Parkinson, 1998). Thus, stakeholding is not regarded as an end in itself but as an effective means of achieving specific goals, as posited by instrumental stakeholder theory (e.g. Stoney and Wistansley, 2001).

Stakeholder theory is also connected with the literature of corporate sustainability and CSR, since it provides a suitable theoretical framework for analyzing the relationship between business and society (Clarkson, 1995; Donaldson and Preston, 1995; Waddock and Graves, 1997a). As Clarkson (1995) argues, making corporate social responsibility a business objective is best undertaken by changing intangible social and environmental issues into tangible stakeholder interests. Thus, the stakeholder approach to corporate governance fits perfectly within the view of the firm that strives to deliver sustainable value to its various stakeholders (Wheeler and Davies, 2004). However, as noted by Ricart et al. (2005), little attention has yet been paid to the implications of corporate sustainability on corporate governance. Neither does there exist any consensus in the literature about which corporate governance variables best represent the stakeholder model. In the following section we will argue for the relevance of three dimensions when analyzing a prostakeholder stance to corporate governance: CSR function at board level, board diversity and stakeholder engagement.

\section{CSR function at board level}

One key issue in the literature on corporate governance is the structure of the board of directors. Board structure refers to the dimensions of the board's organization, covering the number and types of committees, committee membership, and the flow of information among these committees (Zahra and Pearce, 1989). Researchers on agency theory have recommended the creation of compensation and appointment committees, audit committees and shareholder relations committees that would protect shareholders' rights (Demsetz and Lehn, 1985; Jensen and Meckling, 1976). There is 
evidence that setting up these kinds of entities permits directors to deal more specifically with relevant issues affecting the corporation. For instance, Wallace and Cravens (1993) showed that large US public companies with a nomination committee displayed both a market advantage and an accounting-quantified performance advantage over companies without. According to Ricart et al. (2005), adapting board structure to sustainability issues is a fundamental factor in ensuring better quality and depth of overall formulation and implementation of corporate sustainability strategy including the relationships with various stakeholders.

So far, empirical research on the intersection of corporate governance and stakeholder theory has focused either on the perceptions of board members regarding their stakeholders or CSR orientation (Agle et al., 1999; Ibrahim and Angelidis, 1995; Wang and Dewhirst, 1992) or on the representation of stakeholders on the board of directors (Hillman et al., 2001; Luoma and Goodstein, 1999). Some studies have also examined the effects of board composition on a firm's stakeholder performance (Hillman et al., 2001) and corporate social performance (Johnson and Greening, 1999). However, to our knowledge no one has studied the impact of dealing with CSR or sustainable development issues in the boardroom. The integration of CSR issues into board structure will likely lead to a broader governance perspective that takes into account the interests of multiple stakeholders. Thus, considering the evidence found for other board committees, such as audit, compensation and nomination committees, it seems reasonable to propose the existence of CSR function at board level as a reliable indicator for a stakeholder approach to corporate governance and also, following the arguments of instrumental stakeholder theory, as a means to maximize organizational wealth. Thus, we propose the following two hypotheses:

Hypothesis 1a: Explicit CSR function at board level will be positively associated with firmlevel indicators of a stakeholder approach to corporate governance (board diversity and stakeholder engagement).

Hypothesis 1b: Explicit CSR function at board level will have a positive effect on firm financial performance.

\section{Board diversity}

The link between diversity and corporate governance is a relatively new one (Fields and Keys, 2003). Within corporate governance, the concept of diversity relates to board composition and the varied combination of attributes, characteristics and expertise contributed by individual board members in relation to board process and decision-making. On corporate boards, the various types of diversity that may be represented among directors include age, gender, ethnicity, culture, religion, constituency representation, professional background, knowledge, technical skills and expertise, commercial and industry experience, and career and life experience (Milliken and Martins, 1996, cited in Van der Walt and Ingley, 2003, p. 219).

Present research has not been framed within a specific theoretical perspective and has built on different arguments in favor of greater boardroom diversity. On the one hand, moral justifications are mentioned, like the obligation to represent all stakeholder interests in an equitable way, especially formerly underrepresented groups like women and ethnic minorities. On the other, several arguments are made for the business case for board diversity, such as better understanding of the marketplace, increasing creativity and innovation, more effective problem-solving, more effective corporate leadership and more effective global relationships (Carter et al., 2003). Some of these conceptual reasons for promoting board diversity can be supported by resource dependence theory, 
since a more diverse board appears to increase the resources brought in by individual board members and the organization's access to external resources (Van der Walt and Ingley, 2003). Consequently, most researchers assume a positive relationship between board diversity and organizational performance.

Although board diversity has not been connected to stakeholder theory in the literature, the rationale used parallel arguments of normative and instrumental stakeholder theory: corporations have a responsibility to reflect societal diversity in their governance boards, but at the same time this will allow them to establish improved relationships with increasingly diverse stakeholders. Greater demographic diversity on boards will place the firm in a better position to establish links with different stakeholder groups (employees, suppliers, customers). In addition, diversity management has become an important indicator for CSR and corporate citizenship and is used in corporate social ratings systems such as the KLD Indexes or the FTSE4Good Index. Thus, we propose interpreting board diversity as an indicator for the stakeholder approach to corporate governance.

Most of the empirical studies conducted focus on gender and ethnic diversity. Table 1 provides a summary of the studies that examine the presence of women and ethnic minorities on corporate boards and its impact on firm performance or shareholder wealth. All studies are based on samples of large US firms and use secondary data for calculating percentages of women or minorities (i.e. African, Hispanic, Asian and Native Americans) on the board of directors. Whereas Erhardt et al. (2003) and Carter et al. (2003) found significant positive relationships between board diversity and financial performance, the other studies found negative or statistically insignificant relationships. The research of Shrader et al. (1997) has the limitation that it only controls for firm size indirectly and takes no other control variables into consideration, while the research of Zahra and Stanton (1988) has the problem of limited female representation on the boards that were studied (typically one woman per board). Another stream of research has tested the relationship between the proportion of women and minority directors and corporate philanthropy (Coffey and Wang, 1998; Wang and Coffey, 1992; Williams, 2003) and corporate social performance (Siciliano, 1996; Stanwick and Stanwick, 1998), obtaining mostly positive relationships.

\section{Table 1}

Empirical studies on the relationship between board diversity and financial performance

\begin{tabular}{|l|l|l|}
\hline \multicolumn{1}{|c|}{ Study } & \multicolumn{1}{|c|}{ Data } & \multicolumn{1}{c|}{ Findings } \\
\hline $\begin{array}{l}\text { Erhardt et al. } \\
\text { (2003) }\end{array}$ & $\begin{array}{l}\text { 112 large US companies from } \\
\text { different production and service } \\
\text { sectors }\end{array}$ & $\begin{array}{l}\text { Ethnic and gender representation on boards } \\
\text { increases firm financial performance (ROA, } \\
\text { ROI }\end{array}$ \\
\hline Carter et al. (2003) & $\begin{array}{l}\text { 638 US Fortune 1000 firms } \\
\text { pertaining to 8 one-digit SIC code } \\
\text { industries }\end{array}$ & $\begin{array}{l}\text { Presence of women or minorities on } \\
\text { corporate boards positively affects firm value } \\
\text { (Tobin's Q) }\end{array}$ \\
\hline $\begin{array}{l}\text { Shrader et al. } \\
(1997)\end{array}$ & $\begin{array}{l}\text { 200 US firms with the largest } \\
\text { market value }\end{array}$ & $\begin{array}{l}\text { Presence of women on the board is } \\
\text { negatively related to firm financial } \\
\text { performance (ROS, ROA, ROI, ROE) }\end{array}$ \\
\hline $\begin{array}{l}\text { Zahra and Stanton } \\
(1988)\end{array}$ & $\begin{array}{l}100 \text { US Fortune 500 firms from } \\
\text { different sectors }\end{array}$ & $\begin{array}{l}\text { Female and ethnic minority representation on } \\
\text { boards is not associated with firm financial } \\
\text { performance (ROE, profit margin on sales, } \\
\text { net sales-to-equity, EPS, DPS, Log profits) }\end{array}$ \\
\hline
\end{tabular}


To sum up, the existing literature suggests that there are conceptual reasons to associate greater board diversity with increased financial performance, with some empirical evidence to prove this relationship. Thus, we propose the following hypothesis:

Hypothesis 2: Board diversity will have a positive effect on firm financial performance.

\section{Stakeholder engagement}

According to stakeholder theory, firms have to consider the interests of multiple stakeholders in managerial decision-making. Following this argument, Hill and Jones (1992) developed a 'stakeholder-agency theory' and argued that managers should act as 'agents' for stakeholders (the relevant 'principals'). In order to obtain accurate information concerning the expectations of stakeholders, companies have to develop strategies for engaging with stakeholders and for understanding their needs and concerns. Since the goals, priorities and demands of different stakeholder groups are different and often contradictory, scholars usually classify stakeholders into primary and secondary types (Clarkson, 1995; Post et al., 2002; Waddock et al., 2002). The primary or core stakeholder group refers to stakeholders that are essential for the business itself to exist and/or have some kind of formal contract with the business (owners/shareholders, employees, customers and suppliers). The secondary stakeholder group includes social and political stakeholders that play a fundamental role in obtaining business credibility and acceptance of its activities (NGOs/activists, communities, governments and competitors). Furthermore, Driscoll and Starik (2004) broaden the stakeholder definition to include the natural environment, and Hart and Sharma (2004) add the existence of peripheral stakeholders or "fringe" stakeholders as those parties not visible or readily identifiable to the firm.

An active engagement with stakeholders can thus be considered both a condition for and a consequence of the stakeholder approach to corporate governance. Stakeholder engagement processes range from identification of key stakeholders to long-term project teams and partnerships. While it is not the role of the board to be involved in the implementation of tactical programs of stakeholder management, it must ensure that the company is aware of stakeholder needs and takes them into account in board decisions and corporate strategy (for normative and/or instrumental reasons). In this sense, Ricart et al. (2005) report that leading companies in corporate sustainability are using stakeholder engagement mechanisms to a greater extent than other companies.

But despite the important theoretical debate about stakeholder engagement, there has been little empirical research on the benefits of stakeholder relationships for firms. Although several researchers have suggested that the satisfaction of multiple stakeholder needs contributes to firm value creation (Clarkson, 1995; Donaldson and Preston, 1995; Jones, 1995), few studies have attempted to quantify organizational attitudes and behavior towards stakeholders. Within the field of marketing, Greenley and Foxall (1997) and Chung-Leung Luk et al. (2005) analyzed perceptual measures of companies' attentiveness to competitors, customers, employees, shareholders and unions and reported positive effects on business performance. Empirical research framed within the corporate social performance context has used active firm-stakeholder relationships as a predictor variable for financial performance. Table 2 sums up the data and the findings of these empirical studies. 


\section{Table 2}

Empirical studies on the relationship between stakeholder management and financial performance

\begin{tabular}{|l|l|l|}
\hline \multicolumn{1}{|c|}{ Study } & \multicolumn{1}{|c|}{ Data } & \multicolumn{1}{c|}{ Findings } \\
\hline $\begin{array}{l}\text { Hillman and Keim } \\
(2001)\end{array}$ & $\begin{array}{l}\text { 308 US Fortune 1000/Standard \& } \\
\text { Poor's 500 firms pertaining to } \\
\text { different two-digit SIC code } \\
\text { industries }\end{array}$ & $\begin{array}{l}\text { Stakeholder management is positively } \\
\text { associated with shareholder value creation } \\
\text { and leads to improved shareholder value } \\
\text { creation (MVA) }\end{array}$ \\
\hline $\begin{array}{l}\text { Ogden and } \\
\text { Watson (1999) }\end{array}$ & UK water supply companies of the & $\begin{array}{l}\text { Performance on customer service measures } \\
\text { negatively affects current profits (net income) } \\
\text { but significantly enhances shareholders } \\
\text { returns }\end{array}$ \\
\hline $\begin{array}{l}\text { Berman et al. } \\
\text { (1999) }\end{array}$ & $\begin{array}{l}\text { 81 US Fortune 500 firms pertaining } \\
\text { to different four-digit SIC code } \\
\text { industries }\end{array}$ & $\begin{array}{l}\text { Relationships with employees and customers } \\
\text { (product safety/quality issues) positively } \\
\text { affect financial performance (ROA) }\end{array}$ \\
\hline $\begin{array}{l}\text { Waddock and } \\
\text { Graves (1997b) }\end{array}$ & $\begin{array}{l}\text { 469 US Standard \& Poor's 500 } \\
\text { firms pertaining to 13 four-digit SIC } \\
\text { code industries }\end{array}$ & $\begin{array}{l}\text { Improved corporate social responsibility } \\
\text { (which includes stakeholder relations with } \\
\text { employees, customers, communities and } \\
\text { environment) leads to better financial } \\
\text { performance (ROA, ROE, ROS) }\end{array}$ \\
\hline
\end{tabular}

Most of these studies use the Kinder, Lydenberg, Domini and Company (KLD) database (Berman et al., 1999; Hillman and Keim, 2001; Waddock and Graves, 1997b). KLD is a social equity fund consultancy that rates companies on different areas of social performance and particularly on five variables that have been used as measures of stakeholder management: community relations, employee relations, diversity issues, product issues and environment issues. In their study, Ogden and Watson (1999) use specific customer-service performance measures developed for UK water companies, this being the only study not based on samples of large US firms. They all found evidence that well-nurtured relationships with primary stakeholders (mostly customers and employees) have a positive effect on companies' financial performance. Since it appears that relationships with primary stakeholders improve financial performance, we propose the following hypothesis:

Hypothesis 3a: Engagement with primary stakeholders (customers and employees) will have a positive effect on firm financial performance.

Only Hillman and Keim (2001) report a positive effect on firm performance of relationships with secondary stakeholders such as the local community. However, many scholars advocate the importance of engaging with external, non-economic stakeholders (Hart and Sharma, 2004; Sharma and Vredenburg, 1998) in order to build meaningful and sincere relationships which can become the source of competitive advantage. Therefore, we also propose the following hypothesis:

Hypothesis 3b: Engagement with secondary stakeholders (local communities, NGOs, the government, etc.) will have a positive effect on firm financial performance.

\section{Research method}

\section{Sample and data description}

The sample was drawn from the companies assessed within the 2004 annual review for the Dow Jones Sustainability Indexes (DJSI) by SAM Group. SAM Group is an independent asset 
management group that since 1999 has annually assessed economic, environmental and social performance of the Dow Jones Global Index (DJGI) universe. After inviting the 2,500 largest capitalized companies in the world to take part in the assessment, the top 10\% of companies with the best sustainability performance in each of the 60 industry groups are selected for inclusion in the DJSI World. The SAM Group assessment consists of more than 50 general and industry-specific criteria and one of its primary sources of information is a specific questionnaire distributed to the companies participating in the annual review. Further sources include company and third-party documents as well as personal contacts between the analysts and companies. As a result of the assessment, a company's total corporate sustainability score is calculated based on a pre-defined scoring and weighting structure of all criteria, measured with a scale ranging between 0 and 100 .

Reliability and validity of the data are ensured via external review by PricewaterhouseCoopers, which monitors the accuracy of the assessment procedures and results. SAM Group's database has several advantages over the previously-used data provided by social rating organizations, such as KLD. First, a large sample of companies from various countries is included in the database. Second, the assessment undertaken covers a wide range of criteria and thus allows a more fine-grained analysis. Third, the data are primarily based on company responses to a questionnaire which is designed to ensure objectivity by limiting qualitative answers through predefined multiple-choice questions. ${ }^{1}$ In addition, SAM analysts use company documentation, publicly available information and personal contacts to verify and cross-check the data of the completed questionnaires.

For the 2004 DJSI annual review 983 companies were analyzed. We decided to delete companies which were assessed after closing for the DJSI or which were acquired during the period considered. Our sample eventually resulted in 946 firms from 31 countries and operating in 18 different market sectors, according to DJGI classification. The data for financial performance and control variables for each firm were obtained from Datastream.

\section{Measures}

\section{Variables for stakeholder relations}

Our variables for stakeholder relations were constructed out of the responses to SAM Group's Corporate Sustainability Assessment questionnaire. From a question about board responsibilities and committees we identified the companies that have assumed formal responsibility or have created specific committees for dealing with issues of corporate social responsibility, corporate citizenship or sustainable development. With regard to board diversity, the questionnaire includes one question about the percentage made up by the main nationality represented on the board of directors and another about the percentage of women on the board of directors. Thus, we measured board diversity using the variables of nationality and gender. As an indicator of customer engagement, we used a question about how the company integrates customer feedback, and as an indicator for employee engagement we calculated the average score of four items: lay-offs and worker displacement policies, company systems for collecting and handling employee grievances and complaints, company-specific job training, and selection rigor in company recruiting systems. Concerning engagement with stakeholders external to the firm, the questionnaire has one question

\footnotetext{
1 The entire general section of the SAM questionnaire can be downloaded from the website of the Dow Jones Sustainability Indexes (http://www.sustainability-indexes.com).
} 
addressing the number of stakeholders the company regularly addresses through satisfaction surveys or perception studies and one question about the mechanisms used by the company for engaging with these stakeholders. Therefore, we used these two variables of engagement scope and process. As mentioned above, all scores range from 0, indicating a bad performance, to 100 , indicating the best relative performance, with the exception of the variables for CSR function at board level which have been transformed into dichotomous variables.

\section{Variables for financial measures}

As a measure of firm financial performance we used return on equity (ROE) for 2004, which we obtained directly from Datastream. We chose this accounting measure because it is among the most commonly used to indicate company earnings and returns to shareholders, and it conveys a basic sense of the overall profitability of the firms. We removed important outliers, that is, companies that had ROE values greater than 100 or less than -100 . This process left a final data set of 936 companies.

\section{Control variables}

We included in our study several industry-, country- and firm-specific control variables. Prior research has suggested that firm size and industry may influence board diversity and stakeholder management (Carter et al., 2003; Hillman and Keim, 2001; Hillman et al., 2001; Waddock and Graves, 1997a). We measured firm size by the number of employees and created industry dummy variables for the 18 market sectors to which a company is assigned by SAM Group based on its primary revenue source. ${ }^{2}$ Some studies on stakeholder management also indicated a need to control for firm risk (Hillman and Keim, 2001; Waddock and Graves, 1997a), thus we accounted for beta as a proxy for measuring the risk level of the firm. Unlike previous research, the present study uses a sample of companies from different countries. As this fact may have an influence on stakeholder management, we created country dummy variables for the 31 countries where the companies are based. ${ }^{3}$

Since Luoma and Goodstein (1999) found that legal environment influences the adoption of stakeholder-centered board committees, we also wanted to consider the different legal traditions of the countries regarding corporate governance. One of the most influential classifications of countries according to their corporate governance system is the one developed by La Porta et al. (1998). They distinguish between the Anglo-Saxon, French, German and Scandinavian legal traditions. Together, these four categories account for almost every capitalist country in the world (Guillen, 2000). In the literature it has been argued that countries with an Anglo-Saxon legal tradition have favored a shareholder-centered model of corporate governance, whereas countries with a German law tradition are defined in general as following a stakeholder-centered model of governance (Aguilera and Jackson, 2003; Hall and Soskice, 2001). The remaining countries, Scandinavian countries and countries within a French law tradition, are somehow more difficult

\footnotetext{
2 Market sectors are Automobiles, Banks, Basic Resources, Chemicals, Construction, Cyclical Goods \& Services, Energy, Financial Services, Food \& Beverage, Healthcare, Industrial Goods \& Services, Insurance, Media, Non-cyclical Goods \& Services, Retail, Technology, Telecommunications, and Utilities.

${ }^{3}$ Countries are Brazil, Canada, Chile, Mexico, United Status, Austria, Belgium, Denmark, Finland, France, Germany, Greece, Ireland, Italy, Netherlands, Norway, Portugal, South Africa, Spain, Sweden, Switzerland, United Kingdom, Australia, Hong Kong, Indonesia, Japan, Malaysia, Singapore, South Korea, Taiwan, and Thailand.
} 
to classify purely as stakeholder or shareholders economies although most authors would define them as non-shareholder oriented economies, embracing most of the elements of the stakeholder model. The complete list of countries covered in the study is shown in Table 3.

\section{Table 3}

Countries represented in the sample and classified according to La Porta et al. (1998)

\begin{tabular}{|l|r|l|r|l|r|l|r|}
\hline $\begin{array}{c}\text { Anglo-Saxon } \\
\text { legal tradition }\end{array}$ & N & $\begin{array}{c}\text { French } \\
\text { legal tradition }\end{array}$ & N & $\begin{array}{c}\text { German } \\
\text { legal tradition }\end{array}$ & N & $\begin{array}{c}\text { Scandinavian } \\
\text { legal tradition }\end{array}$ & N \\
\hline Canada & 35 & Brazil & 9 & Austria & 4 & Denmark & 7 \\
\hline USA & 325 & Chile & 2 & Germany & 39 & Finland & 10 \\
\hline Ireland & 2 & Mexico & 3 & Switzerland & 26 & Norway & 7 \\
\hline South Africa & 9 & Belgium & 6 & Japan & 126 & Sweden & 21 \\
\hline United Kingdom & 101 & France & 39 & South Korea & 6 & & \\
\hline Australia & 64 & Greece & 5 & Taiwan & 4 & & \\
\hline Hong Kong & 13 & Italy & 23 & & & & \\
\hline Malaysia & 3 & Netherlands & 17 & & & & \\
\hline Singapore & 4 & Portugal & 6 & & & & \\
\hline Thailand & 1 & Spain & 18 & & & & \\
\hline & & Indonesia & 1 & & & \\
\hline
\end{tabular}

\section{Analysis and results}

We use both comparisons of means and regression analysis to test the hypothesized relationships between CSR function at board level, board diversity, stakeholder engagement and firm financial performance. Table 4 provides the means, standard deviations and correlation coefficients for all variables used in the analysis. Average firm size was 38,846 employees, average firm risk was around 1 and average ROE was 15.39\%. 46\% of the firms in the sample have explicitly assumed board responsibility for CSR issues, whereas only $21 \%$ of the firms have created specific CSR board committees. Although the scores for the different variables assessed by SAM cannot really be compared with each other, it appears that firms obtain higher scores in stakeholder engagement issues than in board diversity aspects.

The two variables of CSR function at board level are positively associated with most of the variables of board diversity and stakeholder engagement, though the correlation is stronger with formal CSR board responsibility than with formal CSR committees. While the two variables of board diversity are not correlated at all, the four stakeholder engagement variables are positively correlated with each other. It is noteworthy that board diversity regarding nationalities is positively correlated only with external engagement variables, while board diversity regarding gender is marginally but negatively correlated with customer and employee variables. Finally, our measure of financial performance, ROE, is only significantly and positively correlated with the two diversity variables and the two external stakeholder engagement variables.

Since we know which companies in our sample have assumed formal responsibilities or have created specific committees for dealing with CSR issues, we can test if there is a significant difference in the mean scores of the stakeholder-related and financial variables of this group of companies compared to those that have not assumed such responsibilities. In Table 5 we present t-tests of differences in means for firms with and without CSR board responsibilities or committees. 

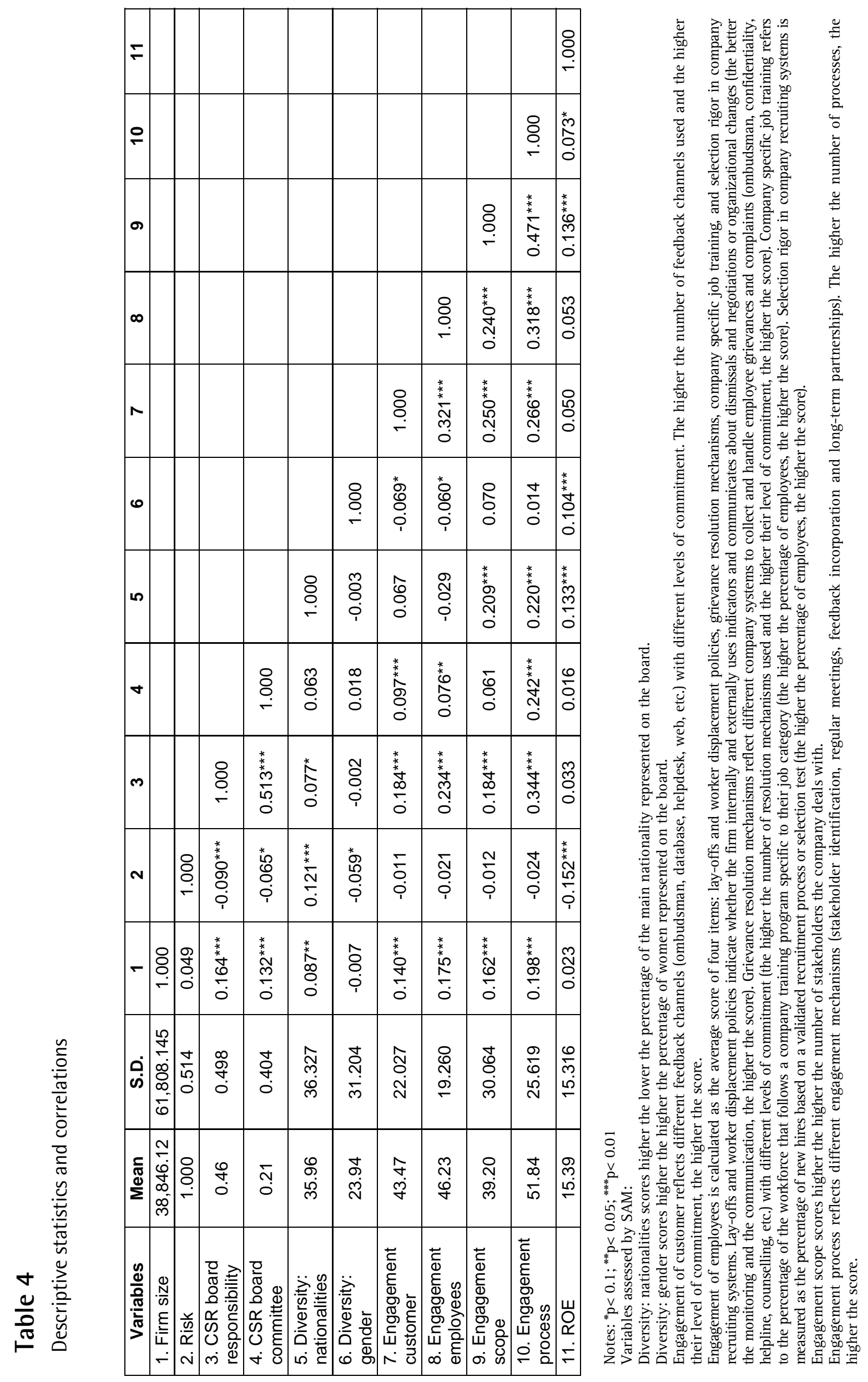


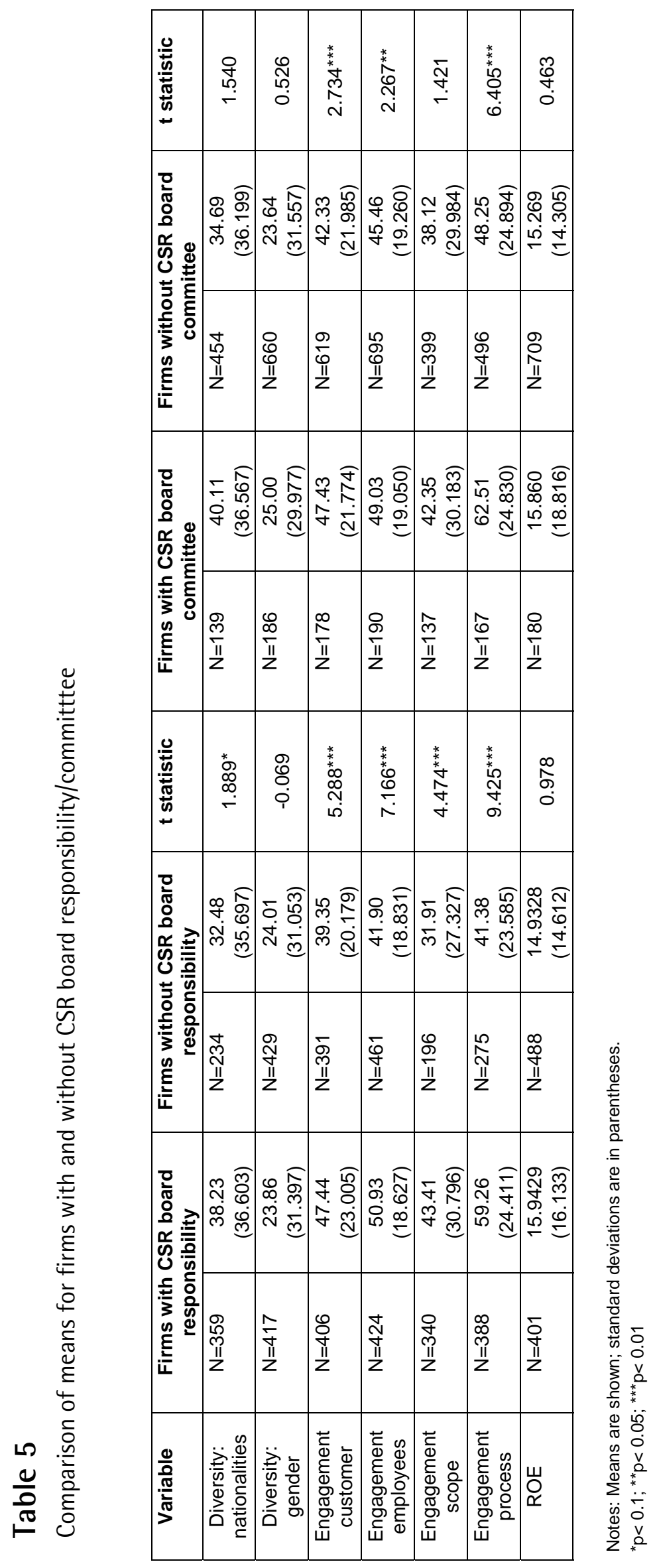


The 426 firms of our sample that have explicitly assumed board responsibility for CSR issues show significantly higher mean scores for engagement with primary and secondary stakeholders: customers, employees, external stakeholders (both scope and process). However, differences regarding the diversity of nationalities on the board are only marginally significant, whereas gender diversity does not show any significant differences. The results for the 192 firms that have created a specific CSR board committee are similar: significant differences exist for the variables of stakeholder engagement (except for scope of external engagement) but no statistically significant differences can be found for board diversity measures. These results partially support Hypothesis 1a, as it appears that CSR function at board level is positively associated with indicators for dealing with primary and secondary stakeholders but not with indicators for more diverse representation on the board. As expected from the observed correlations, the differences found in stakeholder engagement measures are less pronounced for companies with formal CSR committees than for companies with formal CSR board responsibility. With regard to financial performance, we do not find significant differences for ROE between companies with and without CSR board responsibilities or committees (Hypothesis 1b), although the mean values for firms with formal CSR board responsibilities or committees are higher than the values for firms without.

In order to look at the differences between the countries in our sample, we plotted the scores obtained by each country for CSR responsibility on the board on one axis and the average scores obtained for stakeholder engagement on another (see Figure 1). We can observe that countries are not mapped randomly across the two-dimensional space but are displayed along a positive slope. With the exception of those countries which are only represented by a small number of firms and which can thus be regarded as outliers (Indonesia, Thailand, Ireland, Chile, Mexico and Malaysia), countries can be roughly grouped into shareholder-centered and stakeholder-centered countries according to the classification of La Porta et al. (1998). At first glance, countries with an Anglo-Saxon legal tradition (shareholder-centered) obtain lower scores in CSR board responsibility and stakeholder engagement than countries with French, German and Scandinavian legal traditions (stakeholder-centered). Thus, it seems that the distinction shareholder/stakeholder-centered found in previous studies of corporate governance also holds for a stakeholder approach within a CSR strategy. However, it is noteworthy that United Kingdom, South Africa and Canada do not fit into this scheme and have high scores in both of the analyzed dimensions.

Finally, in order to test the relative effects of the dimensions of a stakeholder approach to corporate governance on firm financial performance, we performed multiple regression analysis. The detailed regression results are presented in Table 6. Since we found that it is more relevant when companies assume formal CSR board responsibility than when they create formal CSR committees, we included the first in the models only as an independent dummy variable. When we use the whole sample of all countries (Model 2), only diversity of nationalities on the board (0.217, $\mathrm{p}<0.01)$ and employee engagement $(0.142, \mathrm{p}<0.01)$ have a significant and positive effect on ROE. Whereas CSR board responsibility, board gender diversity and external engagement scope have a positive but not statistically significant impact, customer engagement and external engagement processes show negative effects. After splitting the sample into shareholder-centered and stakeholder-centered countries according to the classification of La Porta et al. (1998), the results change considerably. In shareholder-centered countries none of the independent variables are statistically significant (Model 4), which confirms the expectation that firms in these countries only focus on investor returns. In contrast, companies in stakeholdercentered countries are expected to consider the welfare of other stakeholders as well, and indeed 
we find positive effects of diversity of nationalities on the board $(0.235, \mathrm{p}<0.01)$, board gender diversity $(0.132, p<0.05)$, employee engagement $(0.181, p<0.05)$ and external engagement scope $(0.190, p<0.05)$ (Model 6). CSR board responsibility increases in its positive impact without reaching statistical significance, while customer engagement and external engagement processes maintain their negative association with financial performance.

\section{Table 6}

Regression results for effects of CSR board responsibility, board diversity and stakeholder engagement on financial performance (ROE)

\begin{tabular}{|c|c|c|c|c|c|c|}
\hline \multirow[b]{2}{*}{ Variables } & \multicolumn{2}{|c|}{ All countries } & \multicolumn{2}{|c|}{$\begin{array}{c}\text { Shareholder-centered } \\
\text { countries }\end{array}$} & \multicolumn{2}{|c|}{$\begin{array}{c}\text { Stakeholder-centered } \\
\text { countries }\end{array}$} \\
\hline & Model $1^{a}$ & Model $2^{\mathrm{a}}$ & Model $3^{b}$ & Model $4^{\mathrm{b}}$ & Model $5^{b}$ & Model $6^{b}$ \\
\hline Firm size & $\begin{array}{c}0.055 \\
(0.000)\end{array}$ & $\begin{array}{c}0.049 \\
(0.000)\end{array}$ & $\begin{array}{c}0.061 \\
(0.000)\end{array}$ & $\begin{array}{c}0.104 \\
(0.000)\end{array}$ & $\begin{array}{c}0.009 \\
(0.000)\end{array}$ & $\begin{array}{l}-0.041 \\
(0.000)\end{array}$ \\
\hline Risk & $\begin{array}{c}-0.174^{\star \star \star} \\
(1.223)\end{array}$ & $\begin{array}{l}-0.102^{*} \\
(2.004)\end{array}$ & $\begin{array}{c}-0.232^{* \star \star} \\
(1.539)\end{array}$ & $\begin{array}{l}-0.163^{*} \\
(3.126)\end{array}$ & $\begin{array}{l}-0.066 \\
(2.002)\end{array}$ & $\begin{array}{l}-0.089 \\
(2.496)\end{array}$ \\
\hline $\begin{array}{l}\text { CSR board } \\
\text { responsibility }\end{array}$ & & $\begin{array}{c}0.005 \\
(1.860)\end{array}$ & & $\begin{array}{l}-0.048 \\
(3.034)\end{array}$ & & $\begin{array}{c}0.046 \\
(2.066)\end{array}$ \\
\hline $\begin{array}{l}\text { Diversity: } \\
\text { nationalities }\end{array}$ & & $\begin{array}{l}0.217^{\star \star \star} \\
(0.027)\end{array}$ & & $\begin{array}{c}0.091 \\
(0.038)\end{array}$ & & $\begin{array}{c}0.235^{\star \star *} \\
(0.029)\end{array}$ \\
\hline $\begin{array}{l}\text { Diversity: } \\
\text { gender }\end{array}$ & & $\begin{array}{c}0.064 \\
(0.032)\end{array}$ & & $\begin{array}{l}-0.012 \\
(0.044)\end{array}$ & & $\begin{array}{l}0.132^{\star \star} \\
(0.033)\end{array}$ \\
\hline $\begin{array}{l}\text { Engagement } \\
\text { customer }\end{array}$ & & $\begin{array}{l}-0.040 \\
(0.037)\end{array}$ & & $\begin{array}{c}0.011 \\
(0.059)\end{array}$ & & $\begin{array}{l}-0.048 \\
(0.046)\end{array}$ \\
\hline $\begin{array}{l}\text { Engagement } \\
\text { employees }\end{array}$ & & $\begin{array}{l}0.142^{* \star *} \\
(0.049)\end{array}$ & & $\begin{array}{c}0.084 \\
(0.074)\end{array}$ & & $\begin{array}{l}0.181^{\star *} \\
(0.062)\end{array}$ \\
\hline $\begin{array}{l}\text { Engagement } \\
\text { scope }\end{array}$ & & $\begin{array}{c}0.080 \\
(0.030)\end{array}$ & & $\begin{array}{c}0.025 \\
(0.046)\end{array}$ & & $\begin{array}{l}0.190^{\star *} \\
(0.040)\end{array}$ \\
\hline $\begin{array}{l}\text { Engagement } \\
\text { process }\end{array}$ & & $\begin{array}{l}-0.029 \\
(0.037)\end{array}$ & & $\begin{array}{l}-0.046 \\
(0.062)\end{array}$ & & $\begin{array}{l}-0.049 \\
(0.048)\end{array}$ \\
\hline $\mathrm{R}^{2}$ & 0.117 & 0.213 & 0.086 & 0.234 & 0.035 & 0.179 \\
\hline Adjusted $\mathrm{R}^{2}$ & 0.065 & 0.104 & 0.051 & 0.111 & -0.018 & 0.082 \\
\hline$F$ & $2.236^{\star * *}$ & $1.949^{* \star *}$ & $2.451^{\star \star \star}$ & $1.903^{\star * *}$ & 0.665 & $1.836^{\star * *}$ \\
\hline
\end{tabular}

Notes: Standardized regression coefficients are shown; standard errors are in parentheses.

${ }^{*} \mathrm{p}<0.1 ;{ }^{* *} \mathrm{p}<0.05 ;{ }^{* * *} \mathrm{p}<0.01$

a. Dummy variables were specified to control for market sector and countries.

b. Dummy variables were specified to control for market sector only.

Therefore, we do not find support for Hypothesis $1 \mathrm{~b}$ which suggested higher financial performance for firms with explicit CSR function at board level. Hypothesis 2, stating that board diversity will have a positive effect on firm financial performance, is supported for the whole sample in the case of board diversity with regard to nationality, and also in stakeholder-centered countries for women represented on the board of directors. Hypotheses 3a, stating that engagement with primary stakeholders will have a positive effect on firm financial performance, receives support when considering employee engagement but not when considering customer engagement, which in fact 
seems to lead to decreased ROE. Hypotheses $3 \mathrm{~b}$, stating that engagement with secondary stakeholders will have a positive effect on firm financial performance, is only supported in stakeholder-centered countries with respect to the scope of the engagement; the chosen engagement process seems to be counterproductive for financial improvement.

\section{Figure 1}

CSR board responsibility and stakeholder engagement by countries

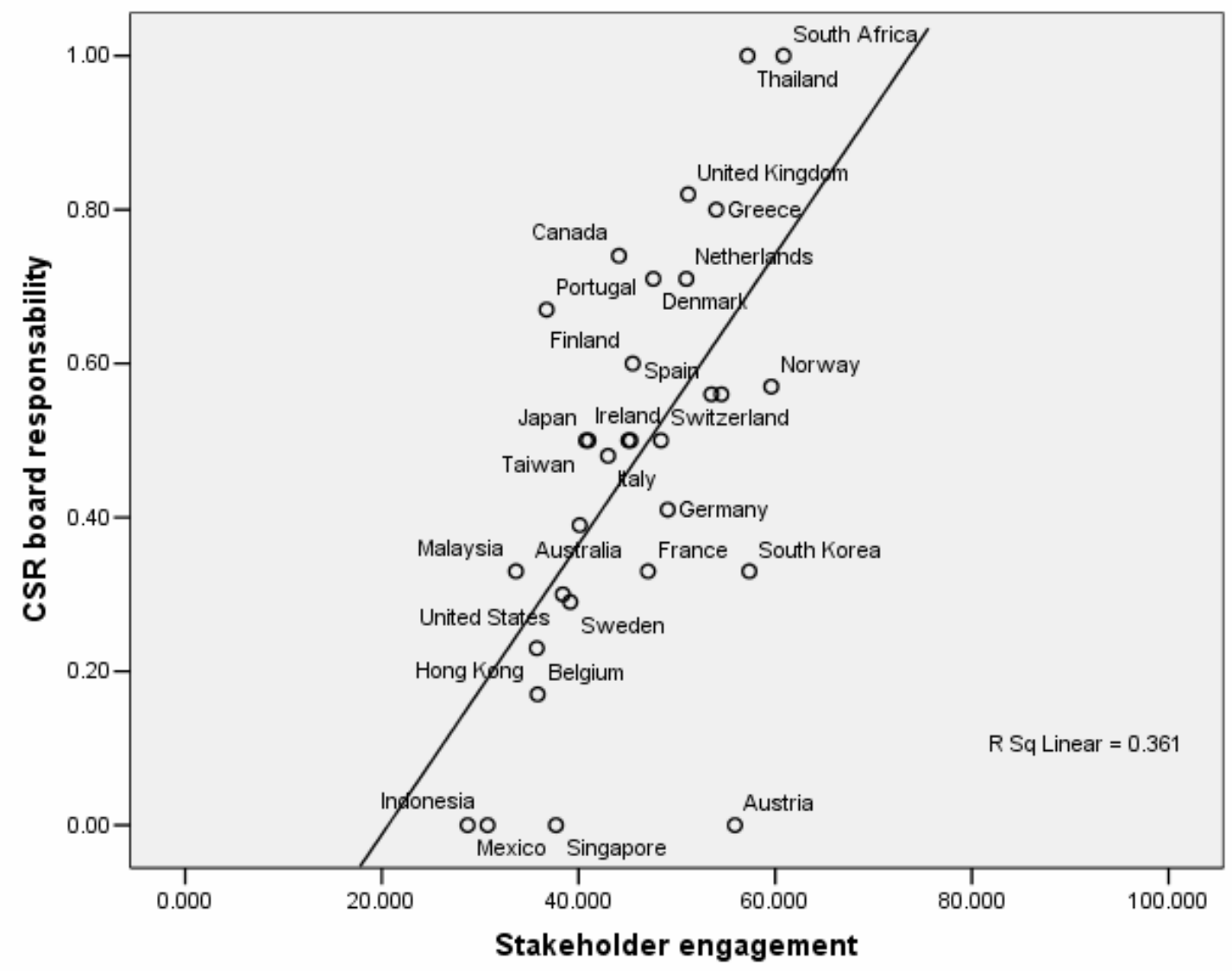

\section{Discussion}

In this paper, we have argued for the relevance of three dimensions when analyzing a prostakeholder stance to corporate governance: CSR function at board level, board diversity and stakeholder engagement. The results of this study confirm that dealing with CSR issues on the board is positively associated with engagement with customers, employees and external stakeholders (local communities, NGOs, government, etc.). This shows that firms that explicitly take the interests of multiple stakeholders into account in their board decisions also make the effort to engage with important primary and secondary stakeholders to understand their needs and concerns. Since the comparison of means delivered better results for companies with CSR board responsibility than for companies with CSR committees, it appears to be more effective to assume the CSR commitment as a board responsibility than to create a formal committee. 
We found that CSR board responsibility and stakeholder engagement are more common in countries with stakeholder-centered models of corporate governance than in countries with shareholder-centered modes of governance. Therefore, it seems that the different national legal traditions affect not only types of finance, ownership and labor relations but also the consideration of non-shareholder-stakeholder interests from a CSR and sustainability perspective. However, the fact that the United Kingdom and South Africa do not fit into this scheme may also indicate that corporate strategy concerning CSR is favored by the specific institutional structures and political legacies of Europe in comparison with other world regions (Doh and Guay, 2006; Welford, 2005).

Our results did not support the hypothesized link between CSR function at board level and board diversity. Due to the available data, board diversity was measured through nationality and gender diversity on the board. Although recent research has assumed that the inclusion of more women and minorities on boards will increase board legitimacy and alter the way the board operates to include more explicit recognition of stakeholder issues (e.g. Hillman et al., 2002), the mere presence of these representatives probably cannot be interpreted as an indicator that corporations are sensitive to issues of boardroom diversity. As highlighted by Zelechowski and Bilimoria (2004), to establish whether women or minority directors are contributing to board diversity, we should measure to what extent their characteristics and qualifications differ from white male officers (background, knowledge, maturity, experience, perspective and prestige).

Following the arguments of instrumental stakeholder theory, we expected to find a positive impact of the different stakeholder-related practices on firm performance measured as ROE. Our regression results indicate that the relationship between stakeholder practices and firm profitability depends on the legal tradition of the country where the company is based. Although previous evidence for the positive effect of board diversity and stakeholder engagement on firm financial performance has been reported for US firms, we only found some support for our theoretical predictions in countries with a corporate governance model oriented towards stakeholders (countries with non-Anglo-Saxon legal tradition). In these countries, more diverse board representation of nationalities and gender, higher engagement with employees and broader scope of engagement with external stakeholders appeared to pay off in terms of increased profitability. Surprisingly, however, a similarly positive relationship could not be observed for the intensity of customer engagement and external engagement processes. An explanation could be the framing of the related questions in SAM Group's questionnaire, which are based on qualitative information. As an indicator for the customer engagement we used a question that lists different ways the company integrates customer feedback with varying degrees of commitment towards the customer (ombudsman, database, helpdesk, web, etc.). For measuring the external engagement process we used a question about the mechanisms put in place by the company for engaging with external stakeholders that reflects very different engagement mechanisms (stakeholder identification, regular meetings, feedback incorporation and long-term partnerships). In comparison to the other variables for stakeholder relations, which are based on more quantitative information, such as percentages, the variables of customer engagement and external engagement processes are less objective, and thus may have an effect on our regression results. Finally, explicit board responsibility for CSR also failed to exhibit a statistically significant impact on financial performance, which indicates that the inclusion of sustainability issues in board decision-making does not make a difference in profitability terms.

However, our findings should be interpreted with caution since additional analyses using alternative measures of financial performance, such as Tobin's Q and Market Value-Added, are 
not significant. Since previous studies have shown that accounting-based measures are better predictors of corporate social responsibility than market-based measures ( $\mathrm{Wu}, 2006)$, further research should explore the suitability of different measures of financial performance. For the time being, research on the relationship between corporate social performance and corporate financial performance is still inconclusive, with some researchers finding a positive linkage, others finding a negative linkage and a third group finding no significant linkage (see Margolish and Walsh (2003) and Orlitzky et al. (2003) for two recent reviews of the impact of CSR on economic performance).

Like all research, our study has some limitations that need to be addressed. Although the SAM Group database probably represents the best externally-based assessment currently available of large corporations worldwide in sustainability issues, it has some weaknesses. In order to allow comparison among all questions of the questionnaire, SAM applies a normalized scoring system based on its own judgment and interpretation. This scale, ranging between 0 and 100, although not publicly available, is surely debatable, above all if it is applied to qualitative information like mechanisms for integrating customer feedback or for engaging with external stakeholders. Another limitation of the study is the fact that some countries have more firms in the sample than others. Although the large sample and the geographical dispersion of the firms included in the analysis increases the external validity of our results, the sample size was very different for each country. There were countries, such as Mexico or Ireland, with 3 or fewer observations in our sample alongside 325 US firms, 126 Japanese firms, 101 UK firms and 64 Australian firms. Finally, the generalizability of our findings is somewhat limited, since our sample consisted of the largest publicly-held companies worldwide with a relatively high level of awareness in CSR issues.

\section{Conclusions}

Although theoretical connections have been made between corporate governance theories and stakeholder theory, and between stakeholder theory and corporate social responsibility (CSR), little research has been conducted on the intersection of corporate governance and CSR or corporate sustainability. CSR suggests that companies have responsibilities that go beyond the interests of their shareholders and must include those of other stakeholders (employees, customers, suppliers, environmentalists, communities, etc.) and the broader society in which they operate. In this sense, the present paper frames the discussion on a stakeholder model of corporate governance within the perspective of the sustainable and responsible firm whose economic survival depends on its ability to satisfy the needs of its various stakeholders.

In an attempt to move forward in firm-level characterization of the stakeholder approach to corporate governance, we have argued for the relevance of three dimensions: CSR function at board level, board diversity and stakeholder engagement. In our study we found evidence that CSR responsibility on the board is positively associated with indicators for dealing with primary and secondary stakeholders but not with indicators of more diverse representation on the board. However, even if board diversity does not seem to be an indicator of the stakeholder approach to corporate governance, it appears to have a positive impact on firm profitability, just as stakeholder engagement with employees and external stakeholders does. Improving on previous empirical research which focused only on US firms, the present study explores the effects of board diversity and stakeholder engagement on firm financial performance by using an 
international sample from 31 different countries and finds that the national context determines the importance of these variables.

Future research should investigate further the influence of country and industry on the adoption of a stakeholder approach to corporate governance. As more data becomes available it would also be useful to determine whether or not the relationships that we have examined hold consistently over time. In order to obtain a broader picture of the benefits of a stakeholding approach, future studies should consider non-financial firm-level performance indicators and analyze the impact of stakeholder practices on these kinds of measures. 


\section{References}

Agle B. R., Mitchell R. K., Sonnenfeld J. A., 1999. Who matters to CEOs? An investigation of stakeholder attributes and salience, corporate performance, and CEO values. Academy of Management Journal 42 (5): 507-525.

Aguilera R. V., Jackson G. 2003. The cross-national diversity of corporate governance: dimensions and determinants. Academy of Management Review 28 (3): 447-465.

Alkhafaji A. F. 1998. A Stakeholder Approach to Corporate Governance: Managing in a Dynamic Environment. Quorum Books: New York.

Berman S. L., Wicks A. C., Kotha S, Jones T. M. 1999. Does stakeholder orientation matter? The relationship between stakeholder management models and firm financial performance. Academy of Management Journal 42 (5): 488-506.

Blair M. M. 1995. Ownership and Control: Rethinking Corporate Governance for the Twenty-first Century. Brookings Institution: Washington, DC.

Carroll A. B. 1996. Business and Society: Ethics and Stakeholder Management, $3^{\text {rd }}$ ed. SouthWestern: Cincinnati.

Carter D. A., Simkins B. J., Simpson W. G. 2003. Corporate governance, board diversity and firm value. Financial Review 38 (1): 33-53.

Chung-Leung L., Yau OHM, Tse ACB, Sin LYM, Chow RPM. 2005. Stakeholder orientation and business performance: The case of service companies in China. Journal of International Marketing 13 (1): 89-110.

Clarke T. 1998. The stakeholder corporation: A business philosophy for the information age. Long Range Planning 31 (2): 182-194.

Clarkson MBE. 1995. A stakeholder framework for analyzing and evaluating corporate social performance. Academy of Management Review, 20 (1): 92-117.

Coffey B. S., Wang J. 1998. Board diversity and managerial control as predictors of corporate social performance. Journal of Business Ethics 17 (14): 1595-1603.

Dalton D. R., Daily C. M., Ellstrand A.E., Johnson J. L. 1998. Meta-analytic reviews of board composition, leadership structure, and financial performance. Strategic Management Journal 19 (3): 269-290.

Demsetz H., Lehn K. 1985. The structure of corporate ownership: Causes and consequences. Journal of Political Economy 93 (6): 1155-1177.

Doh J. P., Guay T. R. 2006. Corporate social responsibility, public policy, and NGO activism in Europe and the United States: An institutional-stakeholder perspective. Journal of Management Studies 43 (1): 47-73.

Donaldson T., Preston L. E. 1995. The stakeholder theory of the corporation: concepts, evidence, and implications. Academy of Management Review 20 (1): 65-91.

Driscoll C., Starik M. 2004. The primordial stakeholder: Advancing the conceptual consideration of stakeholder status for the natural environment. Journal of Business Ethics 49 (1): 55-73.

Erhardt N. L., Werbel J. D., Shrader C. B. 2003. Board of director diversity and firm financial performance. Corporate Governance: An International Review 11 (2): 102-111. 
Fields M. A., Keys P. Y. 2003. The emergence of corporate governance from Wall St. to Main St.: Outside directors, board diversity, earnings management, and managerial incentives to bear risk. Financial Review 38 (1): 1-24

Freeman R. E. 1984. Strategic Management: A Stakeholder Approach. Pitman:Boston.

Gamble A., Kelly G. 2001. Shareholder value and the stakeholder debate in the UK. Corporate Governance: An International Review 9 (2): 110-117.

Greenley G. E., Foxall G. R. 1997. Multiple stakeholder orientation in UK companies and the implications for company performance. Journal of Management Studies 34 (2): 259-284.

Guillén M.F. 2004. Corporate governance and globalization: Is there convergence across countries? In Theories of Corporate Governance, Clarke T (ed). Routledge: New York.

Hall P. A., Soskice D. 2001. Varieties of Capitalism. Oxford University Press: New York.

Hart S. L., Sharma S. 2004. Engaging fringe stakeholders for competitive imagination. Academy of Management Executive 18 (1): 7-18.

Hill CWL, Jones T. M. 1992. Stakeholder-agency theory. Journal of Management Studies 29 (2): 131-154.

Hillman A. J., Cannella Jr. A. A., Harris I. C. 2002. Women and racial minorities in the boardroom: How do directors differ? Journal of Management 28 (6):747-763.

Hillman A. J., Keim G. D., Luce R. A. 2001. Board composition and stakeholder performance: Do stakeholder directors make a difference? Business \& Society 40 (3): 295-314.

Hillman A. J., Keim G. D. 2001. Shareholder value, stakeholder management, and social issues: What's the bottom line? Strategic Management Journal 22 (2): 125-139.

Ibrahim N. A., Angelidis J. P. 1995. The corporate social responsiveness orientation of board members: Are there differences between inside and outside directors? Journal of Business Ethics 14 (5): 405-410.

Jensen M. C., Meckling W. H. 1976. Theory of the firm: Managerial behavior, agency costs and ownership structure. Journal of Financial Economics 3 (4): 305-360.

Johnson R. A., Greening D.W. 1999. The effects of corporate governance and institutional ownership types on corporate social performance. Academy of Management Journal 42 (5): 564-576.

Jones T. M. 1995. Instrumental stakeholder theory: A synthesis of ethics and economics. Academy of Management Review 20 (2): 404-437.

Jones T. M., Wicks A. C. 1999. Convergent stakeholder theory. Academy of Management Review 24 (2): 206-221.

Kelly G., Parkinson J. 1998. The conceptual foundations of the corporation: A pluralist approach. Corporation Financial and Insolvency Law Review 2: 174-197.

La Porta R., López-de-Silanes F., Shleifer A., Vishny R. 1998. Law and finance. Journal of Political Economy 106 (6): 1113-1155.

Letza S., Sun X., Kirkbride J. 2004. Shareholding versus stakeholding: a critical review of corporate governance. Corporate Governance: An International Review 12 (3): 242-262.

Luoma P., Goodstein J. 1999. Stakeholders and corporate boards: Institutional influences on board composition and structure. Academy of Management Journal 42 (5): 553-563.

Margolis J. D., Walsh J.P. 2003. Misery loves companies: Rethinking social initiatives by business. Administrative Science Quarterly 48 (2): 268-305. 
Ogden S., Watson R. 1999. Corporate performance and stakeholder management: balancing shareholder and customer interests in the U.K. privatized water industry. Academy of Management Journal 42 (5): 526-538.

Orlitzky M., Schmidt F. L., Rynes S. L. 2003. Corporate social and financial performance: A metaanalysis. Organization Studies 24 (3): 403-441.

Post J. E., Preston L. E., Sachs S. 2002. Managing the extended enterprise: The new stakeholder view. California Management Review 45 (1): 6-28.

Ricart J.E., Rodríguez M. A., Sánchez P. 2005. Sustainability in the boardroom: an empirical examination of Dow Jones Sustainability World Index leaders. Corporate Governance 5 (3): 24-41.

Sharma S., Vredenburg H. 1998. Proactive corporate environmental strategy and the development of competitively valuable organizational capabilities. Strategy Management Journal 19 (8): 729-753.

Shrader C. B., Blackburn V.B., Iles P. 1997. Women in management and firm financial performance: An exploratory study. Journal of Management Issues 9 (3): 355-372.

Siciliano J. I. 1996. The relationship of board member diversity to organizational performance. Journal of Business Ethics 15 (12): 1313-1320.

Stanwick P. A., Stanwick S. D. 1998. The determinants of corporate social performance: An empirical examination. American Business Review 16 (1): 86-93.

Stoney C., Wistansley D. 2001. Stakeholding: Confusion or utopia? Mapping the conceptual terrain. Journal of Management Studies 38 (5): 603-626.

Sullivan D. P., Conlon D. E. 1997. Crisis and transition in corporate governance paradigms: the role of Chancery Court of Delaware. Law and Society Review 31: 713-763.

Szwajkowski E. 2000. Simplifying the principles of stakeholder management: The three most important principles. Business \& Society 39 (4): 379-396.

Van der Walt N., Ingley C. 2003. Board dynamics and the influence of professional background, gender and ethnic diversity of directors. Corporate Governance: An International Review 11 (3): $218-234$.

Vinten G. 2001. Shareholder versus stakeholder - is there a governance dilemma? Corporate Governance: An International Review 9 (1): 36-47.

Waddock S. A., Bodwell C., Graves S. B. 2002. Responsibility: The new business imperative. Academy of Management Executive 16 (2): 132-148.

Waddock S. A., Graves S. B. 1997a. Quality of management and quality of stakeholder relations: Are they synonymous? Business \& Society 36 (3): 250-279.

Waddock S. A., Graves S. B. 1997b. The corporate social performance - financial performance link. Strategic Management Journal 18 (4): 303-319.

Wallace W. A., Cravens K. S. 1993. Nomination panels strengthen management. Accounting Today 7: 10.

Wang J., Coffey B. S. 1992. Board composition and corporate philanthropy. Journal of Business Ethics 11 (10): 771-778.

Wang J., Dewhirst H.D. 1992. Boards of directors and stakeholder orientation. Journal of Business Ethics 11 (2): 115-123.

Welford R. 2005. Corporate social responsibility in Europe, North America and Asia. Journal of Corporate Citizenship 17 (Spring): 33-52. 
Wheeler D., Davies R. 2004. Gaining goodwill: developing stakeholder approaches to corporate governance. Journal of General Management 30 (2): 51-74.

Wieland J. 2005. Corporate governance, values management, and standards: A European Perspective. Business \& Society 44 (1): 74-93.

Williams R. J. 2003. Women on corporate boards of directors and their influence on corporate philantropy. Journal of Business Ethics 42 (1): 1-10.

$\mathrm{Wu}$ M. L. 2006. Corporate social performance, corporate financial performance, and firm size: A meta-analysis. Journal of American Academy of Business 8 (1): 163-171.

Zahra S. A., Stanton W.W. 1988. The implications of board of directors' composition for corporate strategy and value. International Journal of Management 5 (2): 229-236.

Zahra S. A., Pearce II J. A. 1989. Boards of directors and corporate financial performance: A review and integrative model. Journal of Management 15 (2): 291-334.

Zelechowski D. D., Bilimoria D. 2004. Characteristics of women and men corporate inside directors in the US. Corporate Governance 12 (3): 337-342. 